DOI (Article):https://doi.org/10.31108/2.2021.1.22.12

УДК 159.92:316.647.5

\title{
Терещенко Кіра
}

\section{ТОЛЕРАНТНІСТЬ ЯК ДЕТЕРМІНАНТА ЗАБЕЗПЕЧЕННЯ ПСИХОЛОГІЧНОГО ЗДОРОВ'Я ОСВІТНЬОГО ПЕРСОНАЛУ}

Терещенко Кіра. Толерантність як детермінанта забезпечення психологічного здоров'я освітнього персоналу.

Вступ. Актуальним в сучасних умовах є пошук детермінант психологічного здоров'я освітнього персоналу, до яких слід віднести толерантність.

Мета дослідження: емпірично дослідити види та індекс толерантності персоналу освітніх організацій та вплив показників толерантності на вираженість структурних компонентів його психологічного здоров'я.

Методи дослідження: опитувальник «Індекс толерантності» Г. Солдатової та ін., «Шкала ставлення до психологічного здоров'я» Т. Галкіної, Н. Артемиевої, «Шкала позитивного психічного здоров'я» J. Lukat et al., «Опитувальник для вимірювання локус контролю здоров'я».

Результати дослідження. Встановлено, що види та індекс толерантності впливають на певні структурні компоненти психологічного здоров'я персоналу освітніх організацій.

Висновки. Показники толерантності доцільно розглядати як детермінанти психологічного здоров'я освітнього персоналу.

Ключові слова: толерантність, психологічне здоров'я, детермінанта психологічного здоров'я, індекс толерантності, види толерантності, освітній персонал.

Терещенко Кира. Толерантность как детерминанта обеспечения психологического здоровья образовательного персонала.

Введение. Актуальным в современных условиях является поиск детерминант психологического здоровья образовательного персонала, $\kappa$ которым следует отнести толерантность.

Цель исследования: эмпирически исследовать виды и индекс толерантности персонала образовательных организаџий и влияние показателей толерантности на выраженность структурных компонентов его психологического здоровья.

Методы исследования: опросник «Индекс толерантности» Г. Солдатовой и др., «Шкала отношения к психологическому здоровью» Т. Галкиной, Н. Артемиевой, «Шкала положительного nсихического здоровья» J. Lukat et al., «Опросник для измерения локус контроля здоровья».

Результаты исследования. Установлено, что виды и индекс толерантности влияют на определенные структурные компоненты психологического здоровья персонала образовательных организаций.

Выводы. Показатели толерантности целесообразно рассматривать как детерминанты психологического здоровья образовательного персонала.

Ключевые слова: толерантность, психологическое здоровье, детерминанта психологического здоровья, индекс толерантности, виды толерантности, образовательный персонал.

Вступ. В умовах реформування освіти та соціальної нестабільності, що відображається на діяльності освітніх організацій, дедалі більше уваги приділяється питанням забезпечення психологічного здоров'я освітнього персоналу. Отже, досить актуальним виступає пошук детермінант психологічного здоров'я освітнього персоналу, до яких слід віднести толерантність як інтегральну характеристику особистості, що позначається на міжособистісній взаємодії.

Розкриваючи зміст та структуру поняття «толерантність особистості», зазначимо, що термін «толерантність» походить від лат. tolerantia, що у перекладі означає «терпимість, терпіння». Однак, на думку багатьох учених, толерантність не є пасивною рисою та виходить за межі суто терпимості (Пірен, 2015; Почебут, 2012; Яценко, 2008 та 
ін.). Зокрема, М. Пірен (2015) вказує на те, що толерантність означає не поступку, поблажливість чи потурання, а, передусім, активну позицію, що формується на основі визнання універсальних прав та основних свобод людини, відмову від догматизму та абсолютизму (Пірен, 2015).

Науковці розглядають толерантність як інтегральну характеристику особистості, що передбачає її цілісність та психологічну стійкість (Белашева, 2014; Панченко, 2007). Слід зазначити, що толерантність може проявлятися не тільки на рівні особистості, але й на рівні соціальних груп та інституцій.

Проблема пошуку детермінант психологічного здоров'я персоналу освітніх організацій представлена в працях вітчизняних вчених (Карамушка, \& Снігур, 2020; Карамушка, \& Шевченко, 2017). Різноманітні аспекти толерантності персоналу освітніх організацій висвітлені в роботах вітчизняних та зарубіжних науковців (Брюховецька, 2018; Руда, 2010; Donnelly, 2004 та ін.). Разом із тим, проблема аналізу толерантності як детермінанти психологічного здоров'я освітнього персоналу залишається недостатньо вивченою.

Виходячи із актуальності та недостатнього вивчення проблеми, нами визначено таку мету дослідження: емпірично дослідити види та індекс толерантності персоналу освітніх організацій та вплив показників толерантності на вираженість структурних компонентів його психологічного здоров'я.

\section{Завдання дослідження:}

1. Дослідити види та індекс толерантності персоналу освітніх організацій.

2. Проаналізувати вплив показників толерантності на структурні компоненти психологічного здоров'я освітнього персоналу.

Методи та організація дослідження. Для проведення дослідження використовувалися такі методики.

Для аналізу індексу ma видів толерантності використовувався експресопитувальник «Індекс толерантності» Г. Солдатової, О. Кравцової, О. Хухлаєва, Л. Шайгерової, в якому застосовувався розподіл на субшкали: етнічна толерантність, соціальна толерантність, толерантність як риса особистості (Солдатова, \& Шайгерова, 2008).

Для вимірювання когнітивно-емоційного компонента психологічного здоров'я використовувалася «Шкала ставлення до психологічного здоров'я» (ШСПЗ) Т. Галкіної та Н. Артемцевої (Галкина, \& Артемцева, 2018).

Дослідження рефлексивно-особистісного компонента психологічного здоров'я здійснювалося за допомогою «Шкали позитивного психічного здоров'я» (Positive Mental Health Scale (PMH-scale)) J. Lukat, J. Margraf, R. Lutz, W.M. van der Veld, \& E.S. Becker (Lukat et al., 2016).

Для діагностики операщійно-функиіонального компонента використовувався «Опитувальник для вимірювання локус контролю здоров'я» (Multidimensional Health Locus-of-Control Scales) (Гринберг, 2002). Даний опитувальник складається з трьох шкал: шкали «внутрішнього локусу контролю» (відображає ступінь відчуття опитуваним контролю над своїм здоров'ям); шкали «контролю «могутніми іншими» (показує ступінь впевненості опитуваного в тому, що за його здоров'я несуть відповідальність «могутні інші», наприклад, лікарі, родичі тощо); шкали «контролю випадку» (показує, наскільки опитуваний переконаний в тому, що здоров'я залежить від випадку, удачі або долі).

Обробка результатів здійснювалась методами математичної статистики (описові статистики, кореляційний, дисперсійний аналіз) за допомогою програми SPSS (22 версія).

Дослідження проведено в рамках виконання науково-дослідної теми лабораторії організаційної та соціальної психології Інституту психології імені Г.С. Костюка НАПН України «Психолого-організаційні детермінанти забезпечення психологічного здоров'я персоналу освітніх організацій в умовах соціальної напруженості» (2019-2021рр.), 
науковий керівник - дійсний член НАПН України, доктор психологічних наук, професор Л. Карамушка.

Вибірка дослідження. У дослідженні взяли участь 473 працівники закладів середньої освіти з різних регіонів України. За посадою респонденти були розподілені наступним чином: 20,8\% - педагогічні працівники початкової школи, 29,6\% - середньої школи, 24,5\% - старшої школи, $14.4 \%$ - керівники, $10,2 \%$ - соціальні педагоги та психологи. За віком опитані розподілились наступним чином: 11,4\% - до 30 років, 27,7\% від 31 до 40 років, 34,3\% - від 41 до 50 років, і 26,6\% - понад 50 років. 12,0\% - чоловіки, $88,0 \%$ - жінки; 76,0\% були одруженими, 24,0 \% - неодруженими.

Результати дослідження та їх обговорення. Відповідно до першого завдання емпіричного дослідження, розглянемо результати, які стосуються показників толерантності персоналу освітніх організацій.

Аналіз отриманих даних (табл. 1) свідчить про те, що показники толерантності персоналу освітніх організацій переважно відповідають середньому рівню. Найбільш вираженою є толерантність як риса особистості $(\mathrm{M}=4,16 ; \mathrm{SD}=0,57)$, менш вираженою $є$ етнічна толерантність $(\mathrm{M}=3,94 ; \mathrm{SD}=0,63)$, нарешті, найменш вираженою виступає соціальна толерантність $(\mathrm{M}=3,64 ; \mathrm{SD}=0,51)$.

Таблиия 1

Види та індекс толерантності персоналу освітніх організацій (описові статистики)

\begin{tabular}{|l|l|l|l|l|}
\hline \multicolumn{1}{|c|}{ Види та індекс толерантності } & \multicolumn{1}{c|}{ Min } & \multicolumn{1}{c|}{ Max } & \multicolumn{1}{c|}{ M } & \multicolumn{1}{c|}{ SD } \\
\hline Етнічна толерантність & 2,43 & 6,00 & 3,94 & 0,63 \\
\hline Соціальна толерантність & 2,25 & 6,00 & 3,64 & 0,51 \\
\hline Толерантність як риса особистості & 2,43 & 5,86 & 4,16 & 0,57 \\
\hline Індекс толерантності & 2,64 & 5,82 & 3,90 & 0,46 \\
\hline
\end{tabular}

Дослідження рівнів вираженості видів та індексу толерантності персоналу освітніх організацій (табл. 2) показало, що понад третини респондентів $(37,8 \%)$ мають високий рівень розвитку толерантності як риси особистості, понад чверть опитаних демонструють високий рівень розвитку етнічної толерантності, та лише близько десятої частини опитаних $(11,8 \%)$ характеризуються високим рівнем розвитку соціальної толерантності. Отже, соціальна толерантність, тобто толерантність до представників різних соціальних груп, в умовах суспільної напруженості представлена найменше. Отримані дані подібні до даних О. Брюховецької, за якими соціальна толерантність керівників освітніх організацій $є$ менш вираженою, ніж їхня етнічна толерантність (Брюховецька, 2018).

У цілому, за даними нашого дослідження, менше п'ятої частини респондентів (19,0\%) мають високий індекс толерантності, що свідчить про наявність значних резервів розвитку толерантності педагогічних працівників.

Проаналізуємо результати виконання другого завдання емпіричного дослідження, що стосуються впливу показників толерантності персоналу освітніх організацій на структурні компоненти психологічного здоров'я освітнього персоналу. Насамперед розглянемо вплив видів та індексу толерантності на структурні компоненти психологічного здоров 'я освітнього персоналу. 
Табличя 2

Рівень вираженості видів та індексу толерантності персоналу освітніх організацій (у \% від загальної кількості опитаних)

\begin{tabular}{|l|l|l|l|}
\hline Види та індекс толерантності & $\begin{array}{l}\text { Високий } \\
\text { рівень }\end{array}$ & $\begin{array}{l}\text { Середній } \\
\text { рівень }\end{array}$ & $\begin{array}{l}\text { Низький } \\
\text { рівень }\end{array}$ \\
\hline Етнічна толерантність & 27,3 & 41,4 & 31,3 \\
\hline Соціальна толерантність & 11,8 & 44,5 & 43,7 \\
\hline Толерантність як риса особистості & 37,8 & 45,4 & 16,8 \\
\hline Індекс толерантності & 19,0 & 53,8 & 27,2 \\
\hline
\end{tabular}

Стосовно такого виду як етнічна толерантність, то, як видно з табл. 3, у процесі дослідження констатовано позитивний статистично значущий кореляційний зв'язок між цим видом толерантності та рефлексивно-особистісним компонентом психологічного здоров'я $(\mathrm{r}=0,127 ; \mathrm{p}<0,01)$ та негативний статистично значущий зв'язок між цим видом толерантності та операційно-функціональним компонентом («контроль випадку») (r=$0,279, \mathrm{p}<0,01)$.

Таблиия 3

Зв'язок між видами й індексом толерантності та рівнем вираженості структурних компонентів психологічного здоров'я персоналу освітніх організацій (r)

\begin{tabular}{|c|c|c|c|c|}
\hline \multirow{2}{*}{$\begin{array}{c}\text { Структурні } \\
\text { компоненти } \\
\text { психологічного } \\
\text { здоров'я }\end{array}$} & \multicolumn{3}{|c|}{ Види толерантності } & \multirow[b]{2}{*}{$\begin{array}{c}\text { Індекс } \\
\text { толерантності }\end{array}$} \\
\hline & $\begin{array}{c}\text { Етнічна } \\
\text { толерантність }\end{array}$ & $\begin{array}{c}\text { Соціальна } \\
\text { толерантність }\end{array}$ & $\begin{array}{l}\text { Толерантність як } \\
\text { риса особистості }\end{array}$ & \\
\hline $\begin{array}{l}\text { Когнітивно- } \\
\text { емоційний }\end{array}$ & 0,048 & 0,065 & $0,133^{* *}$ & $0,116^{*}$ \\
\hline $\begin{array}{l}\text { Рефлексивно- } \\
\text { особистісний }\end{array}$ & $0,127^{* *}$ & $0,147^{* *}$ & $0,141^{* *}$ & $0,143^{* *}$ \\
\hline \multicolumn{5}{|l|}{$\begin{array}{l}\text { Операційно- } \\
\text { функціональний: }\end{array}$} \\
\hline $\begin{array}{l}\text { а)«внутрішній } \\
\text { контроль» }\end{array}$ & $-0,048$ & $-0,078$ & $-0,069$ & $-0,076$ \\
\hline $\begin{array}{l}\text { б)«контроль } \\
\text { «могутніми } \\
\text { іншими» } \\
\end{array}$ & $-0,062$ & $0,098^{*}$ & $-0,128^{* *}$ & $-0,052$ \\
\hline $\begin{array}{l}\text { в)«контроль } \\
\text { випадку»» }\end{array}$ & $-0,279^{* *}$ & $-0,220^{* * *}$ & $-0,287^{* *}$ & $-0,307^{* *}$ \\
\hline
\end{tabular}

$* \mathrm{p}<0,05 ; * * \mathrm{p}<0,01$

Дійсно, результати дисперсійного аналізу (ANOVA) (puc.1) також показали, що рівень розвитку етнічної толерантності впливає на рівень вираженості компонентів психологічного здоров'я освітнього персоналу: особистісно-рефлексивного $(\mathrm{p}<0,05)$ та операційно-функціонального («контроль випадку») $(\mathrm{p}<0,001)$.

Стосовно соціальної толерантності, то дані, представлені в табл. 3, свідчать про наявність позитивного статистично значущого кореляційного зв'язку між цим видом толерантності i такими структурними компонентами психологічного здоров'я: рефлексивно-особистісним $(\mathrm{r}=0,147 ; \mathrm{p}<0,01)$ та складовою операційно-функціонального компоненту «контроль «могутніми іншими» $(\mathrm{r}=0,098 ; \mathrm{p}<0,05)$, а також негативного зв'язку між цим видом толерантності та складовою операційно-функціонального компоненту «контроль «випадку» $(\mathrm{r}=-0,220 ; \mathrm{p}<0,01)$. 


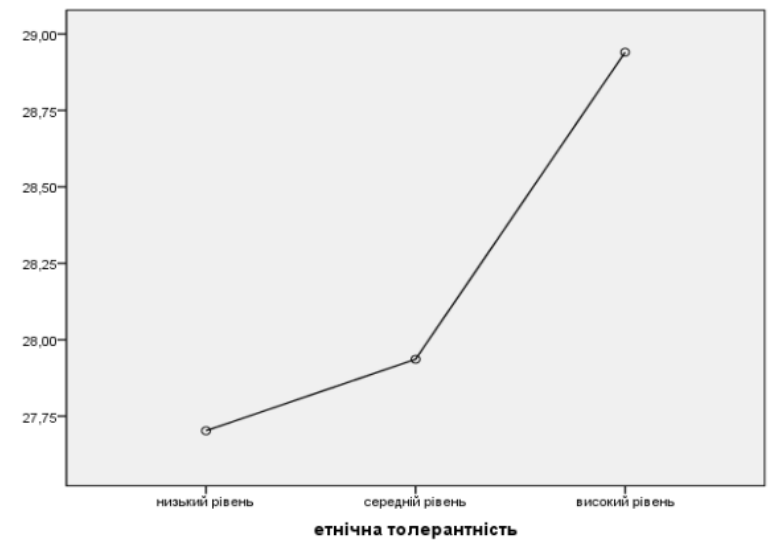

A)

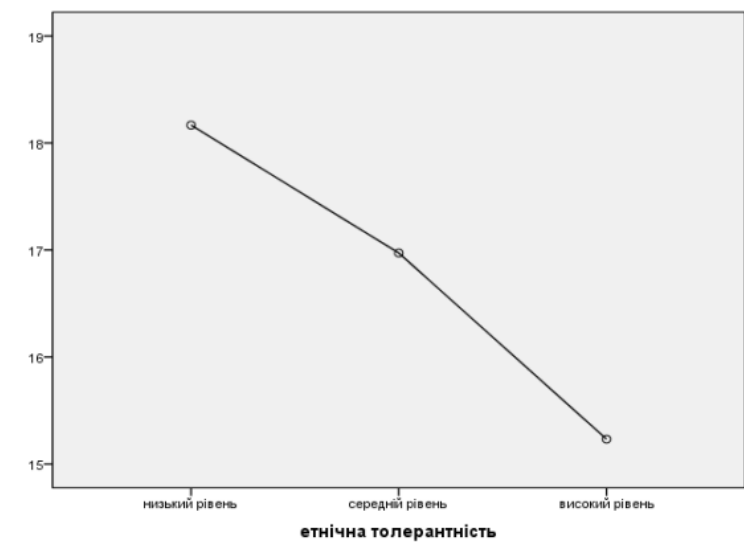

Б)

Рис. 1. Вплив етнічної толерантності на компоненти психологічного здоров'я персоналу освітніх організацій: рефлексивно-особистісний (А); операційнофункціональний(«контроль випадку») (Б)

Згідно з результатами дисперсійного аналізу (ANOVA) (рuc.2), рівень розвитку соціальної толерантності позитивно впливає на рівень вираженості особистіснорефлексивного компоненту психологічного здоров'я освітнього персоналу $(\mathrm{p}<0,01)$ та негативно - на рівень вираженості операційно-функціонального компоненту (складова «контроль випадку») ( $<<0,001)$.

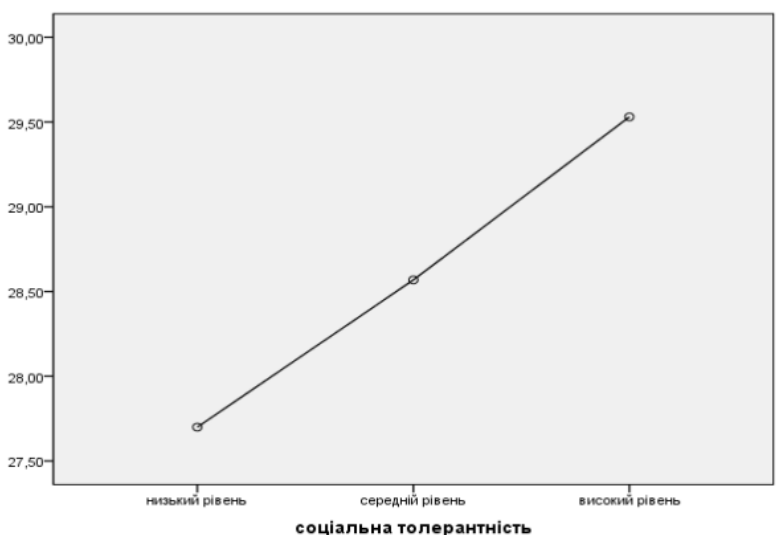

A)

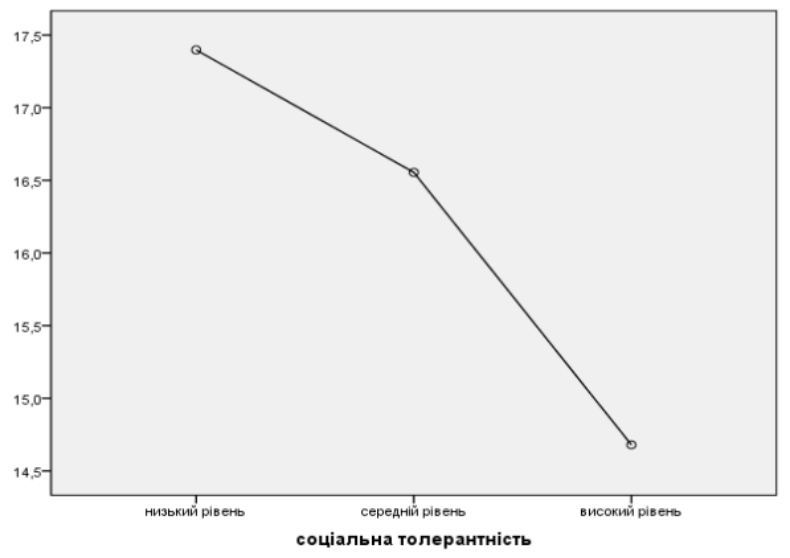

Б)

Рис.2. Вплив соціальної толерантності на компоненти психологічного здоров'я персоналу освітніх організацій: рефлексивно-особистісний (А); операційнофункціональний («контроль випадку») (Б)

Розглянемо складову толерантності «толерантність як риса особистості». Як свідчать отримані дані (табл. 3), існує статистично значущий кореляційний зв'язок, який має різну спрямованість, між цим видом толерантності та усіма компонентами психологічного здоров'я: позитивний зв'язок між цим видом толерантності й когнітивноемоційним $(\mathrm{r}=0,133 ; \mathrm{p}<0,01)$ та рефлексивно-особистісним $(\mathrm{r}=0,141 ; \mathrm{p}<0,01)$ компонентами, а також негативний зв'язок між цим видом толерантності та складовими операційно-функціонального компоненту «контроль «могутніми» іншими» (r=-0,128; $\mathrm{p}<0,01)$ та «контроль випадку» $(\mathrm{r}=-0,287 ; \mathrm{p}<0,01)$. 
Згідно з результатами дисперсійного аналізу (ANOVA) (рuс.3), рівень розвитку

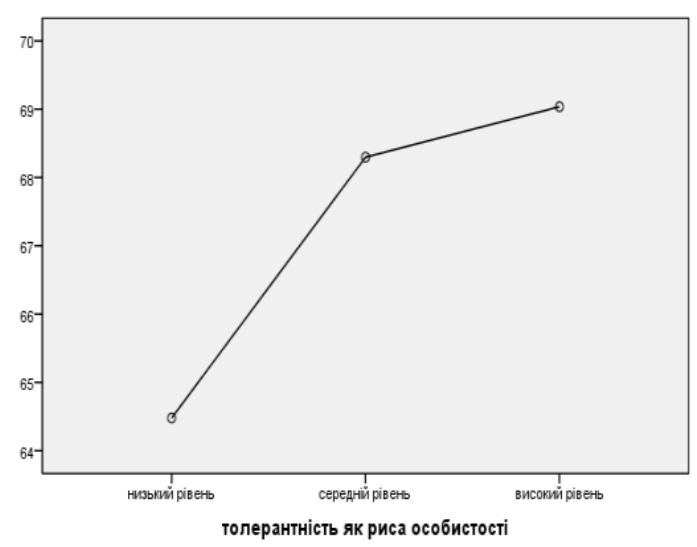

A)

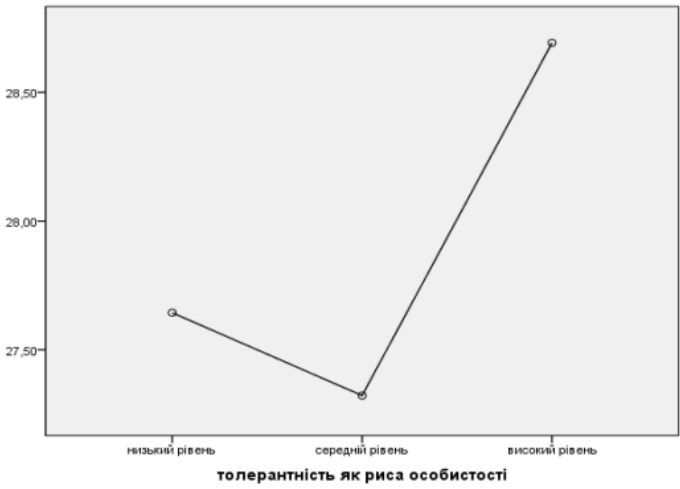

Б)

Рис.3. Вплив толерантності як риси особистості на компоненти психологічного здоров'я персоналу освітніх організацій: когнітивно-емоційний (А); рефлексивноособистісний (Б)

Результати дисперсійного аналізу (ANOVA) (рис. 4) також виявили, що рівень розвитку складової «толерантність як риса особистості» негативно впливає на складові операційно-функціонального компоненту «контроль «могутніми іншими» $(\mathrm{p}<0,01)$ та «контроль випадку» $(\mathrm{p}<0,001)$.

Проаналізуємо зв'язок індексу толерантності з компонентами психологічного здоров'я освітнього персоналу. Як свідчать отримані дані (табл. 3), існує статистично значущий кореляційний зв'язок, який має різну спрямованість, між цим видом толерантності та усіма компонентами психологічного здоров'я: позитивний зв'язок між індексом толерантності й когнітивно-емоційним $(\mathrm{r}=0,116 ; \mathrm{p}<0,05)$ та рефлексивноособистісним $(\mathrm{r}=0,143 ; \mathrm{p}<0,01)$ компонентами, а також негативний зв'язок між цим видом толерантності та складовою операційно-функціонального компоненту «контроль випадку» $(\mathrm{r}=-0,307 ; \mathrm{p}<0,01)$.

Результати дисперсійного аналізу (ANOVA) (puc.5) свідчать, що рівень розвитку індексу толерантності позитивно впливає на когнітивно-емоційний та рефлексивноособистісний $(p<0,05)$ компоненти, а також негативно впливає на складову операційнофункціонального компоненту «контроль випадку» $(\mathrm{p}<0,001)$.

Отже, зазначені види толерантності та індекс толерантності впливають на мінімум два 3 трьох структурних компонентів психологічного здоров'я педагогічних працівників, тобто ці показники толерантності можна розглядати як детермінанти психологічного здоров'я освітнього персоналу.

Слід зазначити, що не виявлено впливу видів та індексу толерантності на складову операційно-функціонального компоненту «внутрішній контроль», що може пояснюватися тим, що така складова локусу контролю здоров'я, як «внутрішній контроль», може знаходитися під впливом комплексу детермінант.

Зворотний зв' язок між видами та індексом толерантності та складовою операційнофункціонального компоненту психологічного здоров'я «контроль випадку» можна пояснити тим, що толерантність сприяє збереженню особистісної цілісності, виявляючись у психологічній стійкості особистості у ситуаціях спрямованого негативного впливу (Белашева, 2014), тобто толерантна особистість відповідальна за все, що з нею відбувається, й не покладається на випадок. 


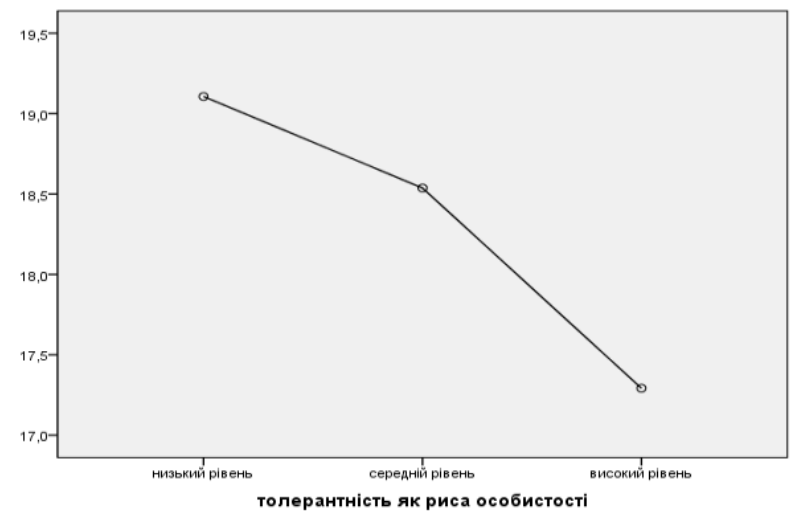

A)

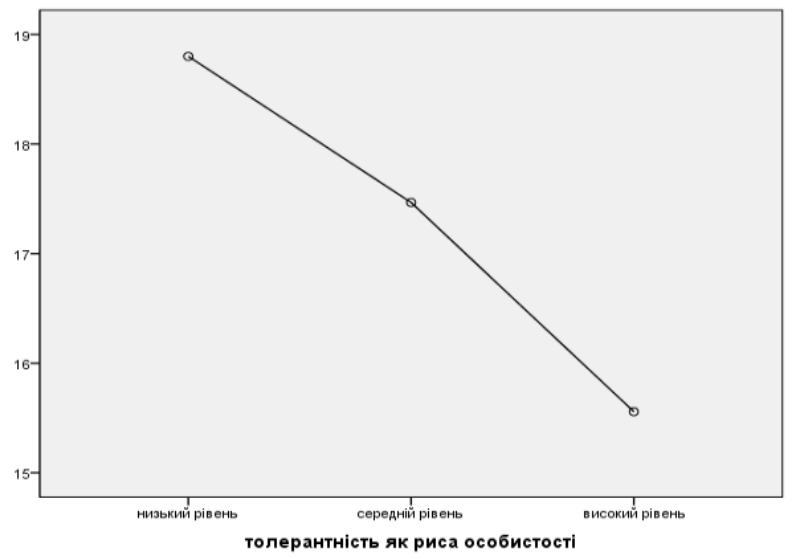

Б)

Рис.4. Вплив толерантності як риси особистості на складові операційнофункціонального компоненту психологічного здоров'я персоналу освітніх організацій: «контроль «могутніми іншими» (А) та «контроль випадку» (Б)

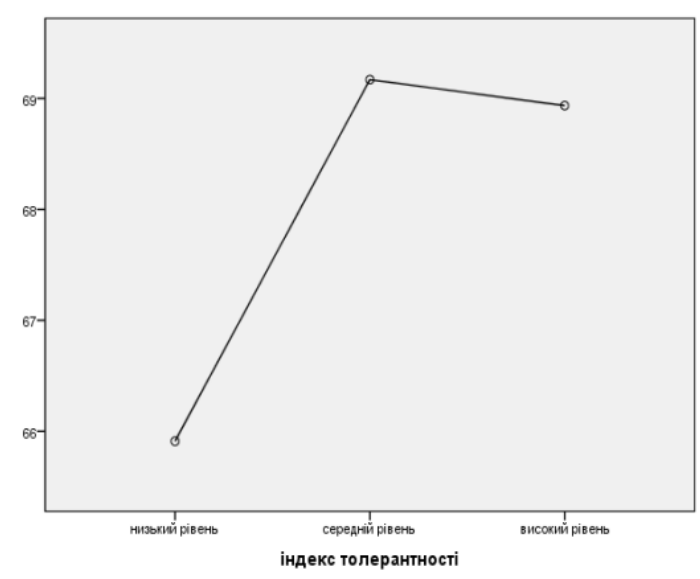

A)

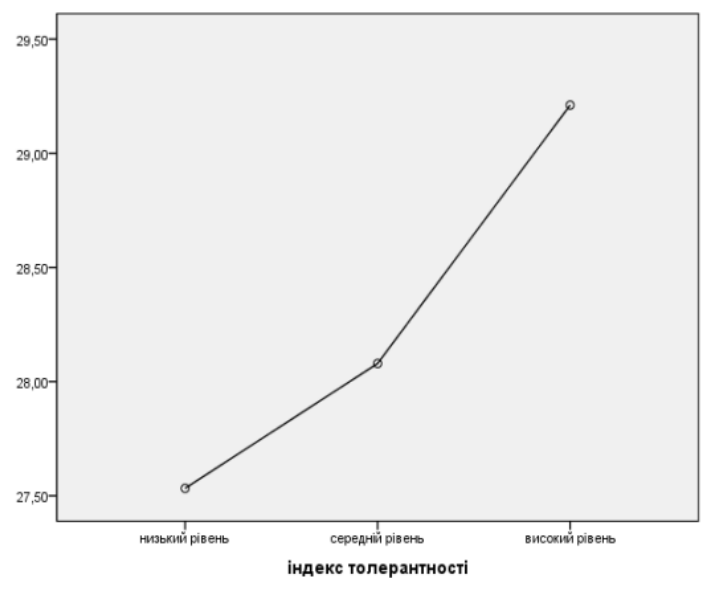

Б)

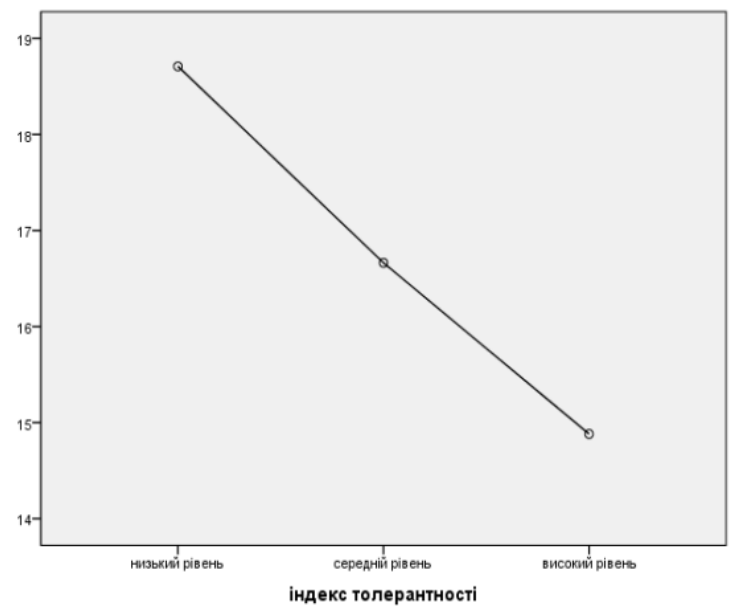

B)

Рис. 5. Вплив загального показника (індексу) толерантності на компоненти психологічного здоров'я персоналу освітніх організацій: когнітивно-емоційний (А); рефлексивно-особистісний (Б); операційно-функціональний(«контроль випадку») (В) 
У цілому результати дослідження свідчать, що серед структурних компонентів психологічного здоров'я освітнього персоналу найбільще підпорядковані впливу показників толерантності рефлексивно-особистісний компонент, на який толерантність здійснює позитивний вплив, та операційно-функціональний компонент, зокрема, така його складова як «контроль випадку», на яку толерантність впливає негативно.

Висновки. Виявлено, що серед видів толерантності освітнього персоналу найбільш вираженою $є$ толерантність як риса особистості, менш вираженою $є$ етнічна толерантність, нарешті, найменш вираженою виступає соціальна толерантність.

Встановлено, що види та індекс толерантності впливають на більшість структурних компонентів психологічного здоров'я педагогічних працівників, тому ці показники можна розглядати як детермінанти психологічного здоров'я освітнього персоналу.

Серед структурних компонентів психологічного здоров'я освітнього персоналу найбільше підпорядковані впливу показників толерантності рефлексивно-особистісний компонент, на який толерантність здійснює позитивний вплив, та операційно-функціональний компонент, зокрема, така його складова як «контроль випадку», на яку толерантність впливає негативно.

Врахування результатів дослідження сприятиме розробці програм забезпечення психологічного здоров'я персоналу освітніх організацій.

Перспективи подальшого дослідження полягають в експериментальному аналізі зв'язку між психологічним здоров'ям та толерантністю персоналу освітніх організацій 3 урахуванням організаційно-професійних та соціально-демографічних чинників.

\section{Література}

1. Белашева, И.В. (2014). Толерантное поведение как критерий психологического здоровья личности. Мир науки, культуры, образования. 6(49). 243-245.

2. Брюховецька, О.В. (2018). Психологія професійної толерантності керівників загальноосвітніх навчальних закладів. Київ: Інтерсервіс.

3. Галкина, Т.В., \& Артемцева, Н.Г. (2018). Взаимосвязь между отношением к психологическому здоровью и самооценкой личности. Психология человека как субъекта познания, общения и деятельности. Москва: Институт психологии РАН.

4. Гринберг, Дж. (2002). Управление стрессом. Санкт-Петербург: Питер.

5. Карамушка, Л.М., \& Снігур, Ю.С. (2020). Копінг-стратегії: сутність, підходи до класифікації, значення для психологічного здоров'я особистості та організації. Актуальні проблеми психології. Організаційна психологія. Економічна психологія. Соиіальна психологія, I(55), 23-30.

6. Карамушка, Л.М., \& Шевченко, А.М. (2017). Психологічні чинники та умови забезпечення психологічного здоров'я менеджерів освітніх організацій. Актуальні проблеми психологіі. Організаційна психологія. Економічна психологія. Соиіальна психологія, I(47), 22-29.

7. Панченко, С.А. (2007). Развитие толерантности как условие сохранения психологического здоров'я подростков. Дисс. канд. психол. наук. Ставрополь.

8. Пірен, М.I. (2015). Толерантність - дієвий чинник злагоди та консолідації в сучасному українському суспільстві. Вісник Національної академії державного управління при Президентові України, 2, 51-56.

9. Почебут, Л.Г. (2012). Кросс-культурная и этническая психология. Санкт-Петербург: Питер.

10. Солдатова, Г.У., \& Шайгерова, Л.А. (2008). Психодиагностика толерантности личности. Москва: Смысл.

11. Руда, О.Ю. (2010).Толерантність у роботі викладача з підлітками. Вісник НТУУ «КПІ». Філософія. Психологія. Педагогіка, 2, 181-184.

12. Яценко, Ю.С. (2008). Воспитание толерантности студентов средствами межкультурной коммуникации в процессе языкового образования. Автореферат дисс. канд. пед. наук. Москва.

13. Donnelly, Caitlin. (2004). Constructing the ethos of tolerance and respect in an integrated school: the role of teachers. British Educational Research Journal, 30, 2. DOI: 10.1080/0141192042000195254

14. Lukat, J, Margraf, J., Lutz, R., vanderVeld, W. M., \& Becker E S. (2016). Psychometric properties of the Positive Mental Health Scale (PMH-scale). BMC Psychology, 4(8).DOI: 10.1186/s40359-016-0111-x

\section{References}

1. Belasheva, I. V. (2014). Tolerantnoe povedenie kak kriterii psikhologicheskogo zdorovya lichnosti [Tolerant behavior as a criterion of psychological health of the individual]. Mir nauki, kultury, obrazovaniya. 6(49), 243-245. [in Russian] 2. Bryukhovetska, O. V. (2018). Psykhologiya profesiinoyi tolerantnosti kerivnykiv zagalnoosvitnikh navchalnykh zakladiv [Psychology of professional tolerance of secondary school principals]. Kyyiv: Interservis. [in Ukrainian]

3. Galkina, T. V., \& Artemtseva, N. G. (2018). Vzaimosvyaz mezhdu otnosheniem k psikhologicheskomu zdorovyu i samootsenkoi lichnosti [The relationship between attitudes toward psychological health and self-esteem]. Psikhologiya cheloveka kak subekta poznaniya, obscheniya i deyatelnosti. Institut psikhologii RAN. [in Russian]

4. Grinberg, Dzh. (2002). Upravlenie stressom [Stress management]. Piter. [in Russian] 
5. Karamushka, L. M., \& Snigur, Yu. S. (2020). Koping-strategiyi: sutnist, pidkhody do klasyfikatsiyi, znachennya dlya psykhologichnogo zdorov'ya osobystosti ta organizatsiyi [Coping strategies: essence, approaches to classification, significance for the psychological health of the individual and the organization]. Aktualni problemy psykhologiyi. Organizatsiina psykhologiya. Ekonomichna psykhologiya. Sotsialna psykhologiya, 1(55), 23-30. [in Ukrainian]

6. Karamushka, L. M., \& Shevchenko, A. M. (2017). Psykhologichni chynnyky ta umovy zabezpechennya psykhologichnogo zdorov'ya menedzheriv osvitnikh organizatsii [Psychological factors in and conditions for ensuring the psychological health of educational organization heads]. Aktualni problemy psykhologiyi. Organizatsiina psykhologiya. Ekonomichna psykhologiya. Sotsialna psykhologiya, 1(47), 22-29. [in Ukrainian]

7. Panchenko, S. A. (2007). Razvitie tolerantnosti kak uslovie sokhraneniya psikhologicheskogo zdorovya podrostkov [Development of tolerance as a condition for maintaining adolescents' psychological health]. Diss. kand. psikhol. nauk. Stavropol. [in Russian]

8. Piren, M. I. (2015). Tolerantnist - diyevyi chynnyk zlagody ta konsolidatsiyi v suchasnomu ukrayinskomu suspilstvi [Tolerance as an effective factor in harmony and consolidation of modern Ukrainian society]. Visnyk Natsionalnoyi akademiyi derzhavnogo upravlinnya pry Prezydentovi Ukrayiny, 2, 51-56. [in Ukrainian]

9. Pochebut, L.G. (2012). Kross-kul'turnaya i etnicheskaya psihologiya [Cross-cultural and ethnic psychology]. Piter. [in Russian]

10. Soldatova, G.U., \& Shajgerova, L.A. (2008). Psihodiagnostika tolerantnosti lichnosti. [Psychodiagnostics of personal tolerance]. Smysl. [in Russian]

11. Ruda, O. Yu. (2010). Tolerantnist u roboti vykladacha z pidlitkamy [Tolerance in teacher's work with adolescents]. Visnyk NTUU «KPI». Filosofiya. Psykhologiya. Pedagogika,2, 181-184. [in Ukrainian]

12. Yatsenko, Yu. S. (2008). Vospitanie tolerantnosti studentov sredstvami mezhkulturnoi kommunikatsii v protsesse yazykovogo obrazovaniya [Developing students' tolerance by means of intercultural communication in the process of language education]. Avtoreferat diss. kand. ped. nauk. Moskva. [in Russian]

13. Donnelly, Caitlin. (2004). Constructing the ethos of tolerance and respect in an integrated school: the role of teachers. British Educational Research Journal, 30, 2. DOI: 10.1080/0141192042000195254

14. Lukat, J, Margraf, J., Lutz, R., van der Veld, W. M., \& Becker, E. S. (2016). Psychometric properties of the Positive Mental Health Scale (PMH-scale). BMC Psychology, 4(8). DOI: 10.1186/s40359-016-0111-x

Tereshchenko, Kira. Tolerance as a determinant of educational staff's psychological health.

Introduction. The determinants of educational staff's psychological health, including their tolerance, has been increasingly drawing attention of researchers.

Aim: to empirically investigate the types and index of educational staff's tolerance and the impact of educational staff's tolerance indicators on the structural components of educational staff's psychological health.

Methods: G. Soldatova et al. Tolerance Index, T. Galkina and N. Artemtseva Attitude to Psychological Health Scale, J. Lukat et al. Positive Mental Health Scale, and the Multidimensional Health Locus-of-Control Scales.

Results. Tolerance as a personality trait has been found to be the most pronounced type of tolerance, followed by ethnic tolerance and social tolerance (the least pronounced). Tolerance type and index affect certain components of educational staff's psychological health. Among the components of educational staff's psychological health that are most responsive to tolerance indicators are the reflexive-personal component (a positive effect) and the operational-functional component, in particular, its "case control» component (a negative effect).

Conclusions. Tolerance indicators should be considered as determinants of educational staff's psychological health.

Key words: tolerance, psychological health, determinants of psychological health, tolerance index, types of tolerance, educational staff.

\section{Відомості про автора}

Терешенко Кіра Володимирівна, кандидат психологічних наук, старший науковий співробітник лабораторії організаційної та соціальної психології Інституту психології імені Г.С. Костюка НАПН України, м. Київ, Україна.

Tereshchenko, Kira Volodymyrivna, $\mathrm{PhD}$ in Psychology, senior researcher, Laboratory of Organizational and Social Psychology, G.S. Kostiuk Institute of Psychology of the NAES of Ukraine, Kyiv, Ukraine.

E-mail: kteresh75@gmail.com

ORCID ID: https://orcid.org/0000 000211492704 